\title{
Pengembangan Pendidikan Agama Berbasis Budaya Sekolah dalam Mengatasi Problematika Pendidikan Agama
}

\author{
Miftakul Khoiri \\ Mahasiswa Pascasarjana UIN Sunan Ampel Surabaya \\ Email : Miftakulkhoiri123@yahoo.com
}

\begin{tabular}{ll}
\hline $\begin{array}{l}\text { Submission } \\
\text { Track: }\end{array}$ & Abstract \\
Received: & $\begin{array}{l}\text { Religious education plays an important role in carrying out development in particular in } \\
\text { shaping and printing young people who are moral and quality. Religious education serves to } \\
\text { make people who believe in obedience to the commands and probibitions of their religion and } \\
\text { apply to everyday life. But what happens in the world of education today does not say so, the } \\
\text { classic problems that occur to date are still not resolved properly and continue to be a continuing } \\
\text { Final Revision: }\end{array} \quad \begin{array}{l}\text { problem. Such as the problem of using time allocation that is too narrow which is used in the } \\
\text { learning process, namely the religious learning elementary school is only } 3 \text { hours face to face and }\end{array}$ \\
junior high school, high school / vocational school is only 2 hours face to face and every hour is \\
Available online:
\end{tabular}

Name \& E-mail Address

Miftakul Khoiri

miftakulkhoiri123@yahoo.com

\section{Keywords: Development Of Religious Education, School Culture, Educational Problems}

\section{Abstrak}

Pendidikan agama memegang peranan penting dalam melaksanakan pembangunan, terkhusus dalam membentuk dan mencetak generasi muda yang bermoral dan berkualitas. Pendidikan agama berfungsi menjadikan manusia yang beriman patuh terhadap perintah dan larangan agamanya serta mengaplikasikan pada kehidupan sehari hari. Namun yang terjadi di dunia pendidikan saat ini tidak berkata demikian, masalah-masalah klasik yang terjadi sampai saat ini masih belum terselesaikan dengan baik dan terus menjadi masalah yang berkelanjutan. Seperti masalah penggunaan alokasi waktu yang terlalu sempit yang di gunakan dalam proses pembelajaran yakni SD pembelajaran Agama nya hanya 3 jam tatap muka dan SMP, SMA/SMK hanya 2 jam tatap muka dan setiap jamnya 45 menit bukan 60 menit, tentunya ini sangat kurang mengingat tujuan pendidikan agama yang begitu besarnya bagi pengembangan dan pembangunan bangsa. Belum lagi apabila dalam satu sekolah terdapat berbagai macam agama. Pengembangan pendidikan agama dengan menerapkan budaya sekolah yang menerapkan prinsip-prinsip pembangunan melalui kegiatan pembelajaran, pemberian nilai dan parameter pencapaian sekolah ini dapat menjadi solusi alternatife berkenaan dengan masalah-masalah yang ada.

Kata Kunci : Pengembangan pendidikan Agama, Budaya Sekolah, Problematika pendidikan

\section{PENDAHULUAN}

Pendidikan di katakan berhasil apabila dapat mengantarkan peserta didik dalam mencapai sebuah tujuan pendidikan. Sesuatu yang di ajarkan selayaknya memang harus yang mudah di pahami langsung oleh peserta didik.(S. Nasution, 1995, p. 35) Seorang guru yang kreatif akan selalu berupaya menciptakan ide-ide dalam merancang sistem pembelajaran yang mampu menghantarkan keberhasilan peserta didik dalam mencapai tujuan pembelajaran. Langkah awal yang 
harus di lakukan oleh guru dalam desaain pembelajaran adalah melakukan analisis terhadap perkembangan peserta didiknya (Wiyani, 2013)

Maka dari itu pendidikan menjadi sesuatu yang sangat penting bagi setiap bangsa terutama bangsa yang sedang membangun. Di sisi lain banyak saja muncul masalah-masalah dan bebagai keluhan tentang pendidikan. Setiap orang menuntut dan menginginkan yang lebih baik, dan seiring berjalan nya waktu juga harus menyesuaikan dengan perkembangan zaman dan teknologi. (Soedijarto, 1986) Pendidikan agama memegang tanggung jawab dan peranan penting dalam mencetak generasi yang berkualitas, lebih-lebih pendidikan agama merupakan landasan atau pijakan moral dalam melaksanakan pembangunan dan pendidikan merupakan kunci untuk menuju pembangunan (Baharuddin, 2016)

Namun beberapa prilaku menyimpang yang di lakukan peserta didik saat ini memang berada dalam tahab yang menghawatirkan. Salah satunya adalah fenomena penyimpangan agama siswa seperti perkelahian antar siswa yang dari setiap tahunnya selalu bertambah (Metro Tempo.com., 2018) Di sisi lain dengan berkembangnya teknologi yang begitu pesat saat ini membuka peluang bebas bagi masyarakat umum terkhusus peserta didik dalam mengakses konten-konten negative, apabila tidak di bentengi dengan pengendalian diri yang kuat. Kejadian seks di luar nikah menjadi yang menjadi tren saat ini menjadi indikator bahwa menurunnya pengendalian diri tersebut. Ini terbukti dengan data statistik yang masuk yang di terbitkan kompasiana.com yang menyatakan bahwa sekitar kurang lebih 62,7\% remaja di Indonesia telah melakukan hubungan seks di luar nikah, 20\% dari 94.270 perempuan mengalami hamil di luar nikah dan kabar buruknya itu terjadi pada kalangan remaja. (Kompasiana.com, n.d.) Kasus-kasus ini diduga merupakan indikator kegagalan pendidikan, khususnya pendidikan agama. Pendidikan agama berada di garda terdepan dalam mempersiapkan sumber daya manusia yang berkualitas.(Al-Munawar, 2003). Hal yang perlu di perhatikan saat ini tidak hanya kecerdasan intelektualnya saja tetapi juga moral dan karakter pendidikan juga harus di jadikan kontribusi dalam menciptakan lingkungan masyarakat yang semakin berbudaya.

Ada beberapa faktor yang memang mempengaruhi tingkat kualitas moral dalam pribadi setiap individu. Salah satunya adalah keteladanan dari seorang guru, orang tua dan masyarakat. Pada saat ini keteladanan di Indonesia di anggap langka, terjadinya berbagai prilaku yang negative yang salah satunya di contohkan oleh kalangan pejabat yang berstatus PNS. Data terakhir menyebutkan bahwa rata-rata yang terjerat kasus korupsi adalah seorang PNS.('ICW', n.d.), dan di mungkinkan seorang guru masuk dalam daftar itu. Kondisi ini menjadikan anak acuh atau tidak peduli lagi dengan nasihat Guru, karena pada saat ini media masa jauh lebih berpengaruh dalam pembentukan karakternya. Akibatnya guru kewalahan dalam membendung budaya negative itu.(Fitri, 2012)

Kelemahan pendidikan agama saat ini terkandung dalam 4 isu utama yakni(Muhaimin, 2006, p. 17) (1) Masalah pada bagian Yayasan Pendidikan agama (2) Masalah struktural (3) Masalah operasional (4) Masalah sejarah. Masalah operasional ini merupakan masalah yang mendasar apabila di kaitkan dengan Pendidikan agama karena pada saat ini memang waktu yang di berikan memang terlalu sempit(Nasution, 1995) Maka dari itu pengembangan budaya Pendidikan agama berbasis budaya sekolah memang seharusnya di lakukan dan ini merupakan solusi alternative untuk di lakukan. Hal ini menjadi tantangan bagi sekolah dalam mengimplematasikan.

\section{METODE PENELITIAN}

Metode penulisan dalam penelitian ini dilakukan dengan menggunakan cara deskriptif 
kualitatif, dalam tulisan ini penulis menggunakan kajian pustaka atau menggali berbagai data dari library research. Penelitian ini merupakan riset atau penelitian kepustakaan. Penelitian kajian pustaka atau riset adalah serangkaian kegiatan yang berhubungan dengan metode pengumpulan data kepustakaan, mencatat dan membaca serta mengolah bahan koleksi yang didapat di perpustakaan tanpa melalui riset di lapangan.(Mestika, 2004)

Menurut Sugiono penelitian Kualitatif berlandaskan filsafat postpositivisme yakni di gunakan untuk meneliti kondisi objek alamiah, di mana peneliti adalah sebagai instrument kunci teknik pengumpulan data dengan triangulasi atau menggabungkan dari berbagai teknik pengumpulan data dan sumber data yang ada. Analisis data bersifat induktif atau kualitatif dan hasil penelitian nya lebih menekankan pada makna daripada generalisasi.(Sugiyono, 2012)

Peneltiian diskriptif kualitatif di tujukan untuk menggambarkan fenomena-fenomena yang ada, baik bersifat alamiah maupun rekayasa manusia dan lebih memperhatikan mengenai kualitas karakteristik antar kegiatan. Selain itu penelitian ini tidak memberikan perlakuan, manipulasi atau perubahan pada variable-variabel yang di teliti dan lebih menggambarkan tentang karakteristik , kualitas dan keterkaitan antar kegiatan.( Sukmadinata, 2011)

Berdasarkan beberapa pendapat ahli di atas dapat di Tarik kesimpulan bahwa penelitian diskriptif kualitatif adalah rangkaian kegiatan penelitian dalam memperoleh data yang bersifat apa adanya tanpa ada manipulasi-manipulasi data dan lebih menekankan pada makna. Di sini penulis menggunakan metode penelitian diskriptif kualitatif di karenakan penulis ingin mengekspor fenomena-fenomena problematika pendidikan agama, terkusus pendidikan agama islam dan budaya sekolah yang terjadi.

\section{HASIL dan PEMBAHASAN}

Isi UU No 20 Tahun 2003 tentang sistem pendidikan nasional di dalamnya merumuskan tujuan dan fungsi pendidikan nasional dalam mengembangkan pendidikan di Indonesia. Pendidikan nasional berfungsi untuk membentuk dan mengembangkan karakter dan peradaban bangsa, dalam konteks intelektual yang bertujuan mengembangkan potensi siswa untuk menjadi orang beriman dan yang memiliki rasa takut akan Tuhan Yang Maha Esa, untuk menjadi mulia, sehat, berpengetahuan luas, mampu, kreatif, mandiri, dan menjadi warga negara yang demokratis dan bertanggung jawab. Tujuan utama Pendidikan nasional memang sudah seharusnya di kembangkan oleh setiap instansi Pendidikan. Oleh karena itu rumusan dalam mencapai tujuan Pendidikan adalah dengan mengembangkan kualitas Pendidikan agama.

Setidaknya ada 6 komponen yang harus diperhatikan dalam mencapai tujuan Pendidikan yang pertama adalah dengan membentuk karakter serta peradaban, yang kedua berkenaan dengan intelektual atau kecerdasan suatu bangsa, yang ketiga dengan menjadikan taat kepada tuhan yang maha esa yang sesuai dengan sila pertama Pancasila, yang keempat menjadikan budaya literasi, kutu buku aktif serta mandiri dalam segala bidang. Yang ke lima menjadi warga negara yang demokratis serta yang terakhir menjadi warga negara yang bertanggung jawab. Dalam hal ini yang di anggap sebagai pihak yang paling mampu untuk melakukan pembinaan adalah instansi - intansi Pendidikan yang memang sudah secara langsung mengarah pada kemajuan dan 
kemandirian baik dari internal maupun eksternal. (Husni Rahim, 2001, p. 11)

Menurut Siregar dalam Asep E. Latip bahwa pembelajaran merupakan sebuah proses yang interaktif dari kegiatan belajar dan mengajar. Perspektif ini mendasari proses pembelajaran yang berakhir pada terciptanya keseimbangan kegiatan yang dilakukan oleh pelajar dan pengajar. Seorang pengajar atau pendidik berperan dalam merencanakan, melaksanakan dan mengevaluasi bahan pengajaran, kemudian memilih metode pengajaran, mengolah media pengajaran, menentukan indikator hasil belajar bahkan menetapkan karakter yang diharapkan. Pembelajar atau peserta didik berperan aktif dalam mengeksplorasi, mengelaborasi dan mengkonfirmasi setiap kegiatan yang difasilitasi oleh pengajar (Latip, 2016)

Kemampuan seorang guru dalam menentukan, membuat kemudian mengaplikasikan sebuah desain pembelajaran akan mempengaruhi keberhasilannya dalam mengajar di sekolah. Karena memang desain pembelajaran adalah sebuah proses perencanaan pembelajaran dalam upaya membantu aktifitas transfer pengetahuan antara guru dan peserta didik. Perencanaan pembelajaran tersebut secara prinsip merupakan penyusuan tujuan pembelajaran, memilih strategi yang tepat dalam pembelajaran, pembuatan materi, serta melakukan evaluasi pada semua komponen pembelajaran. Seorang guru yang kreatif akan selalu berupaya menciptakan ide-ide dalam merancang sistem pembelajaran yang mampu menghantarkan keberhasilan peserta didik dalam mencapai tujuan pembelajaran. Langkah awal yang harus di lakukan oleh guru dalam desaain pembelajaran adalah melakukan analisis terhadap perkembangan peserta didiknya (Wiyani, 2013).

\section{Pendidikan Agama dan Budaya Sekolah}

Pendidikan agama memegang peranan penting dalam membentuk karakter peserta didik, dan hal ini memang sudah sesuai dengan tujuan Pendidikan nasional. Selain memperdalam kemampuan dalam memahami, menghargai dan menerapkan nilai-nilai agama juga untuk membentengi pengaruh dari nilai-nilai negative pada saat ini akibat globalisasi serta untuk melawan kecenderungan matrealisme, konsumerisme dan hedonisme. Pendidikan agama juga bertujuan mengembangkan pemahaman terhadap bentuk atau nilai-nilai keadilan dan menanamkan sikap kuat dan etos kerja dalam realitas social. (Maimun, et. al., 2003). Guna mencapai tujuan Pendidikan yang di inginkan maka penerapan dan pembentukan moral seharusnya di lakukan di rumah, sekolah dan masyarakat. Pendidikan moral haruslah di dukung dengan kelompok kerjasama antara orang tua sekolah dan masyarakat. Di sini sekolah memegang peranan yang penting dalam menggunakan cara yang ada, termasuk memanfaatkan teknologi-teknologi modern. (Al-Munawar, 2003)

Indonesia memang bukan negara yang berbasiskan agama tetapi masyarakatnya sangatlah nasionalis dan agamis. Yang menjadi perhatian pemerintah saat ini salah satunya adalah masalah Pendidikan agama, pada saat ini pendidika agama yang ada di dalam pesantren maupun madrasah, apabila kita cari maka tidak terjadi masalah karena di dalam nya pengajaran Pendidikan agamanya sudah menjadi prioritasm namun berbeda ketika kita melihat Pendidikan agama di sekolah sekolah umum. Di sekolah umum pembelajaran agamanya di anggap 
tidak berhasil dalam membentuk sikap dan prilaku dari peserta didik. Masalah yang ada di dalamnya antara lain :

1. Di dalam pembelajaran Pendidikan agama tidak secara maksimal mengubah pengetahuan agama, dan terfokus pada nilai kognitifnya, sedangkan inti dari Pendidikan agama adalah pada penerapan nya

2. Pendidikan agama di rasa kurang sensitife atau update pada perubahan social, sehingga peserta didik dalam menghargai nilai agama sebagai nilai sehari - hari dalam konteks social budaya kurang.

Pancasila merupakan dasar dan filosofi utama bangsa Indonesia dan pendidikan agama juga merupakan pendidikan dasar utama bagi bangsa Indonesia hal ini sesuai dengan UUD 1945 pasal 29 ayat 1 dan 2 (Purwanto, 1998) Pentingnya pendidikan agama bagi setiap warga Negara Indonesia sudah di mulai sejak di undang undangkan nya tentang pengajaran agama di sekolah umum dan proses integrasi antara pendidikan formal dan agama ini tercantum dalam UUD tahun 1950 dan No 12 tahun 1954 bab XII pasal 20 yang berbunyi (Daulay, 2007):

1. Di sekolah umum pada kelas kateksium atau agama Kristen orang tua berhak menentukan apakah anak-anak mereka akan mengikuti pelajarannya.

2. Tata cara proses pengajaran pendidikan agama di sekolah umum sudah di atur dalam peraturan menteri pendidikan, kebudayaan dan kementerian agama.

Peningkatan pendidikan agama dalam system pendidikan nasional ini berkaitan erat dengan di keluarkannya SKB tiga menteri pada tahun 1975 pada Bab 1 pasal 1 yang berbunyi “ Madrasah adalah sebuah institusi pendidikan yang menjadikan mata pelajaran pendidikan agama islam sebagai dasar perbandingan nya sekitar $30 \%$ di samping mata pelajaran lainnya. Di dalam UU no 2 tahun 1989 bab II bagian 4 pendidikan agama berada dalam situasi yang besar karena menerapkan tujuan Pendidikan nasional, di dalamnya Pendidikan nasional bertujuan untuk menjadikan bangsa Indonesia sebagai bangsa yang cerdas dan selalu berpegang teguh terhadap ALLAH SW'T memiliki kepribadian yang baik, berpengetahuan bertanggung jawab dan nasional (Bab II, Pasal 4 UUSPN). Berkenaan dengan perkembangan sejarah pendidikan agama yang menjadi salah satu pelajaran di sekolah adalah sebagai berikut : (Tafsir, 2008)

1. 1 Juni 1945 Presiden sukarno mengatakan dalam sidang BPUPKI sebuah komite persiapan untuk kemerdekaan Indonesia bahwa taat kepada tuhan yang maha esa merupakan sesuatu yang penting bagi masyarakat Indonesia.

2. 18 Agustus 1945 di tetapkannya prinsip yang pertama yakni percaya pada satu tuhan

3. Pancasila dalam UUD 1945, pasal 29, paragraf 1 dan 2.

4. Di pasal 179 IS (Indische Staatsregeling) Sikap hindia belanda menghadapi pendidikan agama di sekolah sekolah umum yang berbunyi bahwa pembelajaran agama hanya boleh di ajarkan di luar jam sekolah.

5. 27 desember 1945 badan kerja komite Indonesia pusat merekomendasikan PPK (kementerian pendidikan pengajaran dan kebudayaan) untuk mencari pembaruan pendidikan dan pengajaran pendidikan di Indonesia yakni bahwa pengajaran agama yang di selenggarakan PPK mengatakan bahwasannya esensi pesantren dan madrasah 
adalah sesuatu yang harus mendapat perhatian dan dukungan pemerintah karena itu sudah mengakar di masyarakat sebagai salah satu alat dan sumberdaya pendidikan.

6. KH Dewantara mengatur materi pengajaran pendidikan agama melalui komite yang di bentuk menteri PPK kelvin yang menyatakan :

a. Instruksi keagamaan di berikan untuk semua sekolah di mulai dari kelas IV

b. Guru agama di tugaskan langsung dari kementerian agama dan di gaji oleh pemerintah

c. Pesantren dan madrasah yang berkualitas di perbaiki.

7. Pemerintah membentuk kementerian agama tertanggal 3 januari 1946

8. Peraturan PPK bersama menteri Agama tentang pembentukan pengajaran agama di sekolah dasar sejak kelas IV dan berlaku 1 januari 1947.

9. Di keluarkannya UUD No 4 tahun 1950 undang undang pendidikan No 12 tahun 1954 bagian XII pasal 20 tentang pengajaran agama di sekolah-sekolah.

10. Pembentukan pengajaran agama dari tingkat pertama tahun 1951 ( peraturan bersama PPK dan menteri Agama)

11. Menyempurnakan TAP MPRS II Tahun 1960 Bab II Pasal 2 ayat (3) yang menyatakan Mata pelajaran agama di sekolah berlaku mulai dari sekolah dasar hingga universitas negeri

12. TAP MPR No. IV tahun 1973, memasukkan pengajaran agama dalam kurikulum sekolah

13. Dalam UU No. 21989 dalam Bab II, Bagian 4 dari Sistem Pendidikan Nasional menciptakan masyarakat Indonesia cerdas dan menjadikan masyarakat yang beriman dan berbakti kepada Allah SWT dan.....(pasal 4). Dalam pasal 39 ayat 2 dinyatakan bahwa isi kurikulum dari setiap jenis dan tingkatan harus mencakup :
a. Pendidikan Pancasila
b. Pendidikan Agama, dan
c. Pendidikan Kewarganegaraan.

Penjelasan di atas merupakan rentetan atau kronologi sejarah penetapan pembelajaran pendidikan agama islam hingga saat ini, berkenaan dengan budaya sekolah, budaya sekolah adalah seperangkat nilai atau kebiasaan yang di lakukan oleh semua orang yang terlibat di dalam lingkungan pendidikan seperti guru, siswa maupun masyarakat yang berada di sekitar sekolah. Budaya sekolah mempengaruhi sikap emosional, psikologis intelektual peserta didik yang di serap saat berada di lingkungan sekolah. Budaya sekolah memiliki ruang lingkup yang sangat luas. Secara umum termasuk ritual, harapan, hubungan, demografi, kegiatan kurikuler, kegiatan ekstra kurikuler, proses pengambilan keputusan, kebijakan dan interaksi sosial antar komponen di sekolah. Budaya sekolah adalah suasana sekolah tempat siswa berinteraksi dengan teman sebaya, guru dengan guru, penasihat satu sama lain, pejabat administrasi satu sama lain, dan di antara anggota kelompok masyarakat sekolah. Interaksi internal kelompok dan antarkelompok terikat oleh berbagai aturan, norma, moral, dan etika bersama di sekolah. Kepemimpinan, teladan, keramahan, toleransi, kerja keras, disiplin, kesadaran sosial, kesadaran lingkungan, rasa kebangsaan, dan tanggung jawab adalah nilai-nilai yang dikembangkan dalam budaya sekolah (Aminullah, 2010)

Semua yang berada dalam ruang lingkup budaya sekolah yang baik akan dapat langsung berpengaruh terhadap psikologisnya dan dapat membentuk kebiasaan, prilaku maupun nilai dan sikap. Muhaimin mengklafifikasikan budaya sekolah 
dalam 6 sudut pandang, yakni : sudut pandang kemampuan dan perkembangan mentalnya, proses budaya, berdasakan ruang lingkup berdasarkan sumber. Sudut substansial dan dari sudut pandang sifat dari nilai. (Muhaimin, 2006, p. 136) dalam hal lain Rusman mengkonfirmasi dan menyatakan bahwa ekstrakurikuler dengan di dukung intrakurikuler yang komprehensif dan terintegeritas akan dapat lebih mengoptimalkan keberhasilan suatu kurikulum. (Rusman, 2009, p. 20)

Husni Rahim juga menegaskan bahwa posisi kegiatan ekstrakurikuler keagamaan akan dapat menambah nuansa lain dalam proses pembelajaran di dalam kelas. Kegiatan tersebut bertujuan untuk dapat menguasai keterampilan praktis dan keagamaan, siswa terbiasa, dan menciptakan iklim yang kondusif untuk menerapkan keragamannya di lingkungan sekolah. Keterampilan dalam praktik keagamaan ekstrakurikuler harus diabadikan dalam kurikulum atau silabus termasuk prosesi mayat berikut, Haji dan Umrah, perkawinan Islam, sholat terkemuka, sholat, dakwah Jumat, ratiban, maulidan, azan dan iqamah, membaca narator, dan sholat Nabi, dan shalat setelah shalat ( Rahim, 2001)

Budaya sekolah dapat di masukkan dalam kegiatan - kegiatan intrkurikuler maupun ekstrakurikuler sehingga dapat mengembangkan kreativitas serta bakat dan minat siswa. Sekolah merupakan tempat dalam pembinaan aktifitas keagamaan siswa dan merupakan lembaga tempat berjalannya kegiatan pendidikan yang harus mempunyai misi dalam menciptakan budaya sekolah yang menyenangkan, menantang, adil, inovatif, kreatif dan menghasilkan lulusan yang mempunyai karakter takwa, jujur, toleran dan menjawab akan tantangan akan kebutuhan pengembangan sumberdaya manusia yang dapat berperan dalam perkembangan iptek dan berlandaskan imtak (Fitri Rayani Siregar, 2007)

\section{Pengembangan Pendidikan Agama}

Demi menciptakan lingkungan pendidikan yang lebih baik dari sebelumnya maka salah satu yang harus di lakukan adalah dengan mengembangkan Pendidikan agama. Dengan begitu maka pelaksanaan pengajaran pelajaran Pendidikan agamanya dapat lebih optimal dan lebih baik dari sebelumnya. Pengembangan Pendidikan agama di Indonesia saat ini dinilai kurang relistis sehingga yang berkepentingan di dalamnya mengalami kesulitan dalam mewujudkan (Muhaimin, 2006). Pengembangan pendidikan agama pada arah yang tepat, akan menjawab permasalahan-permasalahan yang sering muncul di setiap sekolah. Di antaranya bahwa pada saat ini Pendidikan agama hanya di nilai dari segi kognitifnya saja tanpa memperhatikan pengembangan penilaian afektif dan psikomotorik dan masihbelum di sinkronkan dengan mata pelajaran yang lain.

Ibadah, pada saat ini hanya di pahami sebagai sebuah agama saja bukan sebagai pembentuk kepribadian. Pendekatan agama juga masih bersifat sebagai perbuatan yang normatife saja kurang mengembangkan upaya bagaimana mengembangkan metodologi yang masih bersifat monoton hanya menggunakan pendekatan behavioris yang mengandalkan stimulus" dan tidak menggunakan pendekatan kontruktivis sebagai bentuk dari pengembangan. Paradigma atau pemikiran saat ini masih cenderung bersifat dikotomik belum mengarah ke mechanism, organisme atau paradigma sistemik. (Khuzaimah, 2017)

Berdasarkan ketentuan UUD no 2 tahun 1990 tentang system Pendidikan nasional maka struktur organisasi jalur Pendidikan sekolah yang di 
tuangkan dalam peraturan pemerintah sebagai berikut :

1. No 27 tahun 1990 tentang Pendidikan prasekolah menyatakan bahwa bentuk sebuah Pendidikan dan pelatihan adalah sebagai berikut anak-anak yang berusia 3 tahun maka berada dalam wilayah kelompok bermain dan anakanak yang berusia 4-6 tahub berada pada kelompok taman kanak-kanak dan bentuk lainnya berada pada rentang waktu 1 sampai 2 tahun

2. No 28 tahun 1990 tentang Pendidikan dasar. Pada Pendidikan dasar rentang waktunya adalah 6 tahun baik itu SDLB maupun MI. dan bentuk Pendidikan yang berada dalam rentang 3 tahun adalah SMP / SMPLB dan MTs.

3. No 29 tahun 1990 tentang Pendidikan menengah. Pada Pendidikan menengah ini di bagi menjadi dua kelompok yaitu Pendidikan menengah umum dan Pendidikan menengah kejuruan.

Menurut Ivan Illich memberikan pendapat, menurutnya sekolah adalah proses yang berkaitan dengan batas usia dan guru harus selalu hadir di dalamnya sesuai kurikulum wajibnya karena instansi Pendidikan pada saat ini di anggap sebagai rumah kedua setelah keluarga yang slah satunya mengajarkan tentang Pendidikan agama. (Agus Maimun et al., 2003, p. 2) lingkungan Pendidikan sangatlah besar pengaruhnya dalam pembentukan karakter atau moral peserta didik proses pembiasaan dan peniruan sangatlah tinggi maka dari itu di dalamnya juga harus di berikan suri tauladan yang baik di samping proses pemberian pengetahuan atau ketrampilan.

Secara umum, pendidikan agama berfungsi untuk menumbuhkan dan mengembangkan kemampuan peserta didik dalam memahami dan mempraktekkan nilai nilai agama di samping di barengi dengan penguasaan ilmu-ilmu yag lain. (Fauzan, 2007) kewajiban sekolah di samping mengajarkan pengetahun yang bersifat kognitif juga harus berusaha dalam membangun karakter pribadi dari peserta didik, tidak berguna apabila peserta didik dalam segi kognitif / pengetahuannya sangat pintar namun di sisi lain karakter, kepribadian serta prilakunya tidak baik menurut Ngalim Purwantu lingkungan sekolah memang di klasifikasikan ke dalam lingkungan yang kedua setelah lingkungankeluarga dan terakhir lingkungan masyarakat(Purwanto, 1998) Di samping keluarga, pada saat ini sekolah di anggap sebagai tempat pembelajaran agama untuk anak. Pendidikan agama yang di ajarkan di sekolah antara lain sikap saling tolong menolong dan memiliki sikap yang baik bertanggung jawab menghargai teman guru disiplin jujur dll..

\section{Pengembangan Pendidikan Agama Berbasis \\ Budaya Sekolah}

Mukti Ali berpendapat bahwasanya proses pembelajaran yang berlangsung dalam pembelajaran Pendidikan agama, seharusnya tidak hanya berfokus kepada pemberian pengetahuan saja. Di dalamnya juga harus terdapat proses transaksional dan proses transinternalisasi. Proses transaksional adalah hubungan timbal balik antara guru dan murid, yang mana di antaranya terdapat interaksi dan komunikasi antara satu dengan yang lain dan proses transinternalisasi adalah pemberian pemahaman berkenaan dengan sikap dan tingkah laku. Maka dari itu di perlukan pengembangan pendidikan agama agar tidak hanya dari segi kognitifnya saja yang meningkat, tetapi dari segi nilai universalnya juga 
meningkat agar menciptakan karakter luhur siswa.(Maimun et al., 2003, p. 31)

Pendidikan agama adalah pendidikan yang penuh dengan pembentukan sikap, ini berbeda dengan mata pelajaran yang lain, yang lebih pada segi kognitifnya. Strategi yang di gunakan lebih pada strategi belajar afektif. Strategi belajar afektif terkait dengan nilai” yang sulit di ukur yang mana tidak hanya mengandalkan pengetahuan saja dan tujuan nya lebih kepada pembentukan sikap atau karakter siswa, maka proses pembelajaran oleh guru haruslah di bangun sejak awal. Pembanguna Pendidikan agama berbasis budaya haruslah di lakukan dan harus mencakup prinsip-prinsip dari pembangunan yang di lakukan melalui proses pembelajaran, penilaian dan evaluasi.

Pada prinsipnya pengembangan Pendidikan agama berbasis budaya sekolah mengacu pada prinsip budaya religi. Pendidika agama tidak hanya memberikan pemahaman tentang agama saja tetapi yang lebih penting dari itu, membuat peserta didik atau anak lebih taat kepada tuhan yang maha esa dan juga membuat peserta didik dalam kehidupan kesehariannya berprilaku sesuai dengan norma norma agama masing - masing dengan prinsip :(Ngalim Purwanto, 1998, p. 158) (1) Di lakukan dengan terus menerus. (2) Proses pengembangan diri terintegrasi ke dalam mata pelajaran dan budaya sekolah. Maka dari itu seorang guru dan sekolah seharusnya sudah memasukkan nilai-nilai Pendidikan agama ke dalam kurikulum sekolahnya baik dalam silabus maupun RPP (Rencana program pembelajaran).

Perkembangan Pendidikan agama dalam budaya sekolah ini tidak hanya di lihat dari seberapa banyak menghafalkan tapi di lihat dari seberapa sering itu di lakukan. Maka dari itu muhaimin membedakan model evaluasi Pendidikan agama menjadi tiga dan salah satunya adalah referensi model etika(Muhaimin, 2009, pp. 21-22), ini di karenakan sesuatu yang di evaluasi ini adalah berkenaan dengan kepribadian, referensi model etika ini di dasarkan pada pemahaman bahwa asal usul dari manusia yakni baik dan pendidikan berupaya untuk mengembangkan fitrah tersebut dalam kesatuan iman sains dan amal. Implikasi dari referensi evaluasi model etika ini adalah terhadap tujuan dari pembelajaran yakni membuat manusia menjadi lebih baik dan berbakti kepada tuhan yang Maha Esa.

\section{KESIMPULAN}

Pendidikan agama memegang peranan penting dalam melaksanakan pembangunan terkhusus dalam membentuk dan mencetak generasi muda yang bermoral dan berkualitas. Setidaknya ada 6 komponen yang harus diperhatikan dalam mencapai tujuan Pendidikan yang pertama adalah dengan membentuk karakter serta peradaban, yang kedua berkenaan dengan intelektual atau kecerdasan suatu bangsa, yang ketiga dengan menjadikan taat kepada tuhan yang maha esa yang sesuai dengan sila pertama Pancasila, yang keempat menjadikan budaya literasi, kutu buku aktif serta mandiri dalam segala bidang. Yang ke lima menjadi warga negara yang demokratis serta yang terakhir menjadi warga negara yang bertanggung jawab.

Mengingat tujuan pendidikan agama yang begitu besarnya bagi pengembangan dan pembangunan bangsa maka, masalah - masalah yang terjadi dalam pembelajaran pendidikan agama harus segera di atasi. Masalah operasional pendidikan merupakan masalah yang mendasar apabila di kaitkan dengan Pendidikan agama, karena pada saat ini alokasi waktu yang di berikan pada pembelajaran 
pendidikan agama memang terlalu sempit. Maka dari itu pengembangan budaya Pendidikan agama berbasis budaya sekolah merupakan solusi alternatife untuk mengatasi masalah tersebut. Pada prinsipnya, pengembangan Pendidikan agama berbasis budaya sekolah mengacu pada prinsip budaya religi. Pendidikan agama tidak hanya memberikan pemahaman tentang agama saja tetapi yang lebih penting dari itu, membuat peserta didik atau anak lebih taat kepada tuhan yang maha esa dan juga membuat peserta didik dalam kehidupan kesehariannya berprilaku sesuai dengan norma norma agama yang seharusnya. Pengembangan pendidikan agama dengan menerapkan budaya

\section{DAFTAR PUSTAKA}

Agus Maimun, Abdul Muksti Basir, \& Hasanudin. (2003). Profil Pendidikan Agama Islam (PAI) Sekolah Umum Tingkat Dasar. Jakarta: Departemen Agama RI Direktorat Jenderal Kelembagaan Agama Islam Direktorat Madrasah Dan Pendidikan Umum Proyek Pemberdayaan Kelembagaan Dan Ketatalaksanaan Pada Madrasah Dan PAI Pada Sekolah Umum Tingkat Dasar.

Al-Munawar, S. A. H. (2003). Aktualisasi Nilai-nilai Qur'an Dalam Sistem Pendidikan Islam. Jakarta: Ciputat Press.

Aminullah, M.. (2010). Pengembangan Pendidikan Buadaya Dan Karakter Bangsa Pedoman Sekolah. Yogyakarta: DIP PTA IAIN Sunan Kalijaga.

Baharuddin, H. (2016). Pembaruan Pendidikan Islam Azyumardi Azra: Melacak Latar Belakang Argumentasinya. Lentera Pendidikan: Jurnal Ilmu Tarbiyah dan Keguruan, Vol. 16, No. 2, 196-204.

Daulay, Haidar Putra. (2007). Sejarah Pertumbuhan dan Pembaruan Pendidikan Islam di Indonesia. Jakarta: Prenada Media.

Fitri, Agus Zaenul. (2012). Pendidikan Karakter berbasis Nilai dan Etika di Sekolah. Yogyakarta: ArRuzz Media.
Fauzan. (2007). Dilema Baru Pendidikan Islam Pasca Otonomi Daerah. Mimbar Jurnal Agama Dan Budaya, Vol. 24 No. 4.

ICW: Setiap Tahun Rata-Rata 350 PNS Diduga Terlibat Korupsi | Kabar24. (n.d.). (Online) Retrieved from: https:/ / kabar24.bisnis.com/read/20190220/1 6/891299/icw-setiap-tahun-rata-rata-350-pnsdiduga-terlibat-korupsi. Diakses 23 November 2019,

Khuzaimah, K. (2017). Paradigma Pengembangan Kurikulum Pendidikan Agama Islam di Sekolah (Analisis berbagai Kritik terhadap PAI). Jurnal Kependidikan, Vol. 5, No. 1, 105-118.

Kompasiana.com. (n.d.). 63 Persen Remaja Di Indonesia Melakukan Seks Pra Nikah. Retrieved, from: https://www.kompasiana. $\mathrm{com} /$ rumahbelajar_persada/63-persenremaja-di-indonesia-melakukan-seks-pranikah_54f91d77a33311fc078b45f4. Diakses 24 November 2019

KPAI: Tawuran Pelajar 2018 Lebih Tinggi Dibanding Tahun Lalu - Metro Tempo.co. (n.d.). (Online) Retrieved from: https://metro.tempo.co/ read/1125876/kpaitawuran-pelajar-2018-lebih-tinggi-dibandingtahun-lalu. Diakses 28 November 2019

Latip, A. E. (2016). Pembelajaran Berbasis Karakter Di Madrasah Ibtidaiyah. Jurnal Pendidikan Islam, Vol. 28, No. 1, 40-58.

Mestika, Zed. (2004). Metode Penulisan Kepustakaan. Jakarta: Yayasan Bogor Indonesia.

Muhaimin. (2006). Nuansa Baru Pendidikan Islam Mengurai Benang Kusut Dunia Pendidikan. Jakarta: PT.Raja Grafindo Persada.

(2009). Pengembangan Kurikulum Pendidikan Agama Islam di Sekolah, Madrasah, dan Perguruan Tinggi. Jakarta: PT. Raja Grafindo Persada.

Nasution, Harun. (1995). Islam Rasional Gagasan dan Pemikiran. Bandung: Mizan.

Nasution, S.. (1995). Berbagai Pendekatan Dalam Proses Belajar Mengajar. Jakarta: Bumi Aksara.

Purwanto, Ngalim. (1998). Ilmu Pendidikan Teoritis Dan Praktis. Bandung: PT. Remaja Rosdakarya.

Rahim, Husni. (2001). Kendali Mutu Pendidikan Agama Islam. Jakarta: Departemen Agama RI Direktorat Jenderal Pembinaan Kelembagaan Agama Islam. 
Rusman. (2009). Manajemen Kurikulum. Jakarta: Rajawali Pers.

Siregar, Fitri Rayani. (2017). Nilai-Nilai Budaya Sekolah dalam Pembinaan Aktivitas Keagamaan Siswa SD IT Bunayya Padangsidimpuan. Jurnal Kajian Gender dan Anak Pusat Studi Gender dan Anak (PSGA), Vol. 1 No. 1, 1-11.

Soedijarto. (1986). Menuju Pendidikan Nasional yang Relevan dan Bermutu. Jakarta: Balai Pustaka.

Sugiyono. (2012). Metode Penelitian Kuantitatif Kualitatif dan R\&DD. Bandung: Alfabeta.

Sukmadinata, Nana Syaodih (2011). Metode Penelitian Pendidikan. Bandung: PT. Remaja Rosdakarya.

Tafsir, Ahmad. (2008). Metodologi Pengajaran agama Islam. Bandung: Remaja Rosdakarya.

UU No.20 Thn 2003 - Sistem Pendidikan Nasional. (n.d.). Retrieved from http://hukum.unsrat.ac.id/uu/uu_20_03.htm. Diakses 22 November 2019,

Wiyani, Novan Ardy. (2013). Desain Pembelajaran Pendidikan. Yogyakarta: Ar-Ruzz Media. 
